\title{
Nutritional status of schoolchildren aged 7-10 years enrolled in public and private schools of Cascavel, Paraná, Brazil
}

\author{
Estado nutricional de escolares de sete a \\ 10 anos de escolas públicas e privadas \\ de Cascavel, Paraná, Brasil
}

Karina Elaine de Souza SILVA ${ }^{1}$

Andreia PELEGRINI²

André de Araújo PINTO²

Enio Ricardo Vaz RONQUE ${ }^{3}$

Edilson Serpeloni CYRINO ${ }^{3}$

Antonio de Azevedo BARROS FILHO ${ }^{4}$

A B S T R A C T

\section{Objective}

To analyze the prevalence of malnutrition, overweight, and obesity in schoolchildren aged 7-10 years from public and private schools of Cascavel, Paraná, Brazil.

\section{Methods}

Demographic information (sex, age, and type of school) and anthropometric measurements (body mass and height) were collected from 2,180 students (1,693 from public schools and 487 from private schools). The nutritional status of the children was classified according to their body mass index Z-score.

\section{Results}

The prevalences of malnutrition, overweight, and obesity were $6.1 \%, 9.8 \%$ and $11.1 \%$, respectively. Girls were $15.9 \%$ more likely to be malnourished than boys. As for overweight, 10-year-olds were 1.53 times more

\footnotetext{
1 Universidade Estadual de Londrina, Centro de Educação Física e Esporte, Departamento de Educação Física. Rod. Celso Garcia Cid, Km 380, 86057-970, Londrina, PR, Brasil. Correspondência para/Correspondence to: KES SILVA. E-mail: <kkasilva@yahoo.com.br>.

2 Universidade do Estado de Santa Catarina, Centro de Ciências da Saúde e do Esporte, Programa de Pós-Graduação em Ciências do Movimento Humano. Florianópolis, SC, Brasil.

${ }^{3}$ Universidade Estadual de Londrina, Centro de Educação Física e Esporte, Programa de Pós-Graduação Associado em Educação Física. Londrina, PR, Brasil.

${ }^{4}$ Universidade Estadual de Campinas, Faculdade de Ciências Médicas, Programa de Pós-Graduação em Saúde da Criança e do Adolescente. Campinas, SP, Brasil.
} 
likely to be overweight than 7-year-olds. Children from private schools were 1.63 times more likely to be overweight and 2.88 times more likely to be obese than their public school peers.

\section{Conclusion}

The prevalence of malnutrition and excess weight (overweight and obesity) were high, and girls were more likely to be malnourished. Ten-year-olds and children from private schools were the most affected by overweight and obesity.

Keywords: Malnutrition. Obesity. Overweight. Health children.

\section{RE S U M O}

\section{Objetivo}

Analisar a prevalência de desnutrição, sobrepeso e obesidade em escolares de sete a 10 anos em estudantes de escolas públicas e privadas de Cascavel, Paraná, Brasil.

\section{Métodos}

Informações demográficas (sexo, idade e rede de ensino) e medidas antropométricas (massa corporal e estatura) foram obtidas de 2180 escolares (1 693 de escolas públicas e 487 de privadas). Os valores do Escore-Z do indice de massa corporal foram adotados para a determinação do estado nutricional.

\section{Resultados}

As taxas de prevalência de desnutrição, sobrepeso e obesidade foram na ordem de 6,1\%, 9,8\% e 11,1\%, respectivamente. As meninas apresentaram mais chances (15,9 vezes) para o desenvolvimento de desnutrição do que os meninos. Por outro lado, crianças de 10 anos apresentaram mais chances (1,53 vezes) para desenvolverem sobrepeso em relação aos seus pares de sete anos. Adicionalmente, crianças de escolas privadas apresentaram mais chances para o desenvolvimento de sobrepeso (1,63 vezes) ou obesidade (2,88 vezes), em relação aos seus respectivos pares de escolas públicas.

\section{Conclusão}

As taxas de prevalência de desnutrição e excesso de peso reveladas neste estudo foram elevadas, com as meninas apresentando mais chances para tornarem-se desnutridas do que os meninos. Em contrapartida, tanto o sobrepeso quanto a obesidade foram fenômenos mais frequentemente observados aos 10 anos, em escolares de ambos os sexos e naqueles matriculados na rede privada de ensino.

Palavras-chave: Desnutrição. Obesidade. Sobrepeso. Saúde da criança.

\section{NTRODUCTION}

The nutritional status of children and adolescents has been the target of numerous Brazilian ${ }^{1-4}$ and international5-8 ${ }^{5}$ studies. These data are critical because of the influence of underweight and excess weight (overweight and obesity) on the risk of early-onset metabolic disorders and chronic noncommunicable diseases ${ }^{1,3}$.

In this sense, a gradual reduction in the prevalence of malnutrition has been observed in Brazilian children aged 5-10 years ${ }^{1}$. The Pesquisa Nacional de Orçamentos Familiares ${ }^{2}$ found that the prevalence of malnourished males decreased from $5 \%$ to $2 \%$ from $1974 / 1975$ to 1989 , and increased to $4 \%$ in $2008 / 2009$. Similarly, the prevalence of malnourished females decreased from $5.4 \%$ to $1.5 \%$ from $1974 / 1975$ to 1989 , and increased to $3.9 \%$ in 2008/2009. These data diverge from African data, where malnutrition continues to be an important public health problem ${ }^{9,10}$.

On the other hand, a significant increase in the prevalence of overweight and obesity has been observed in Brazilian children aged 5-10 years ${ }^{1}$. From 1974/1975 to 2008/2009, the prevalence of overweight males increased from $10.9 \%$ to $34.8 \%$, and that of overweight females, from $8.6 \%$ to $32.0 \%$. During the same period, the 
prevalence of obese males increased from 2.9\% to $16.6 \%$, and that of obese females, from $1.8 \%$ to $11.8 \%{ }^{1}$. A recent Brazilian meta-analysis about obesity in children and adolescents found a prevalence of $14.1 \%$, which did not differ by sex $(16.1 \% \text { vs. } 15.0 \% \text {, respectively })^{4}$.

In Brazil childhood overweight and obesity are important public health problems that affect children of all ages, more in the South and Southeast regions than in the North/Northeast regions, probably because of the socioeconomic differences between the populations living in these regions ${ }^{1,3}$. Moreover, a higher prevalence of overweight and obesity has been observed in children from private schools compared with children from public schools ${ }^{2,3,11}$. This phenomenon deserves attention and its analysis may promote the establishment of specific intervention actions $^{12-14}$.

Based on the supposition that the prevalences of underweight, overweight, and obesity can be affected by sociodemographic and behavioral factors, the purpose of this study was to analyze the prevalence of malnutrition, overweight, and obesity, and the associated factors in a representative sample of schoolchildren aged 7 to 10 years from public and private schools of Cascavel (PR), Brazil. The initial hypotheses of this study were that children from public schools should have a higher prevalence of malnutrition and that children form private schools should have higher prevalences of overweight and obesity, regardless of gender.

\section{METHODS}

The municipality of Cascavel is in the western region of the state of Paraná, ranking sixth in the state with respect to demographics. The estimated population is 309,259 inhabitants $^{15}$. Cascavel has a Municipal Human Development Index of 0.692, ranking fifteenth in the state. The local population descends mostly from Italian, German, and Polish immigrants. The number of first graders to fourth graders aged seven to ten years old, respectively, is estimated to be 21,763 according to the municipal School Census, of which 19,030 are enrolled in public schools and 2,733 , in private schools. The municipality was divided into five quadrants for selecting the study schools: North, South, East, West, and Downtown. An urban public school was then randomly selected from each quadrant $(n=5)$, and five private schools were sampled by convenience.

The sample size was determined as suggested by the literature ${ }^{16}$, using a confidence level of 1.96 (95\% Confidence Interval [95\% Cl]), an error of 3\%, a prevalence of $50 \%$ (unknown outcome), and a design effect of 1.5. Thus, the minimum sample size estimated for this study was 1,526 children. To compensate for students who might refuse to participate in the study, an extra $20 \%$ was added, so the sample consisted of 1,831 students.

All children aged 7 to 10 years enrolled in the selected schools in 2004 were eligible for the study. The inclusion criteria were: 1) self-reported good health (not taking any medication frequently or not being treated for some disease) and 2) provided an informed consent form signed by the parents or guardians. The exclusion criteria were: 1) voluntary refusal to participate in the study and 2) absent from school on the data collection day. Hence, the total sample consisted of 2,180 students (Table 1), of which 1,693 (887 boys and 806 girls) and 487 (226 boys and 261 girls) were from public and private schools, respectively. This study is part of the project "Crescimento e aptidão física relacionada à saúde em escolares do município de Cascavel, PR" (Growth and physical aptitude related to health in schoolchildren from the municipality of Cascavel, PR). After being informed about the objective of the present study and the respective procedures, all parents or guardians signed an informed consent form. This study complied with the Declaration of Helsinki and was approved by the Research Ethics Committee of the Universidade Estadual do Oeste do Paraná (State University of Western Paraná) (Opinion 126/2004-CEP/CCBS). 
Table 1. Distribution of the sample by age, gender, and type of school.

\begin{tabular}{lccccc}
\hline & \multicolumn{2}{c}{ Female $(\mathrm{n}=1.065)$} & & \multicolumn{2}{c}{ Male $(\mathrm{n}=1.115)$} \\
\cline { 6 - 6 } \cline { 6 - 6 } & $\mathrm{n}$ & $(\%)$ & & $\mathrm{n}$ & $(\%)$ \\
\hline Age (years) & & & & & \\
7 & 296 & 27.8 & & 291 & 26.1 \\
8 & 272 & 25.5 & & 279 & 25.0 \\
9 & 281 & 26.4 & & 299 & 26.8 \\
10 & 216 & 20.3 & & 246 & 22.1 \\
Type of school & & & & & \\
Public & 806 & 75.7 & & 887 & 79.6 \\
Private & 259 & 24.3 & & 228 & 20.4 \\
\hline
\end{tabular}

Demographic data (gender, age, and type of school) and anthropometric measurements (body mass and height) were collected from all participants. Body mass was measured by a digital scale (FilizolaTM, São Paulo, SP, Brazil), with accuracy of $0.1 \mathrm{~kg}$ and capacity of $150 \mathrm{~kg}$, and height was measured by the compact wallmounted stadiometer SECA Corporation, (SECA 220, model 206, Hamburg Germany) with accuracy of $0.1 \mathrm{~cm}$ and length of 2.20 meters $^{17}$. Body Mass Index (BMI) was given by dividing the body mass in kilograms $(\mathrm{kg})$ by the square of the height in meters ( $m$ ).

The nutritional status of the children was classified according to BMI Z-score as follows ${ }^{18}$.

(a) Underweight (Z-score <-2);

(b) Normal weight $(-2<$ Z-score $<+1)$;

(c) Overweight $(+1<$ Z-score $<+2)$;

(d) Obesity (Z-score $>+2$ ).

Descriptive procedures were used initially to represent the schoolchildren from public and private schools. The independent samples $t$-test identified the differences between the groups. Overweight and obesity prevalences were established according to the study variables (sex, age, and type of school). Since the dependent variable (nutritional status) consisted of four categories (normal weight, malnutrition, overweight, and obesity), multinomial logistic regression was used for estimating the association between nutritional status and the independent variables (gender, age, and type of school). The normal weight category was defined as the reference group. The analyses were adjusted for all variables, regardless of $p$ value. All analyses used a significance level of $5 \%(95 \% \mathrm{Cl})$. The analyses were performed by the software Statistical Package for the Social Sciences for Windows, version 20.0 (SPSS Inc., Chicago, IL, USA).

\section{RE S U L T S}

Table 2 shows the general characteristics of the sample. Students from private schools had statistically higher body mass, height, and body mass index than those from public schools $(p<0.05)$.

Figure 1 shows the BMI Z-scores of the entire sample.

The study prevalences for malnutrition, overweight, and obesity were $6.1 \%, 9.8 \%$, and $11.1 \%$, respectively (Table 3 ). Girls $(11.6 \%$ ), children aged 7 to 8 years $(7.5 \%$ and $7.8 \%$, respectively), and children from public schools (6.2\%) had higher prevalences of malnutrition. Overweight was more prevalent in boys (11.2\%), children aged 8 years (12.0\%), and children from private schools $(11.9 \%)$. Obesity was more prevalent in girls (14.8\%), children aged 10 years $(14.1 \%)$, and children form private schools (17.5\%).

Table 4 shows the odds ratios for malnutrition, overweight, and obesity. Malnutrition was associated with gender, indicating that girls were 15.9 times more likely to be malnourished than boys. Overweight was associated with age, indicating that 10-year-olds were 1.53 times more likely to be overweight than seven-year-olds. Additionally, children from private schools were 1.63 and 2.88 times more likely to be overweight and obese, respectively, than their public school peers. 
Table 2. General characteristics of schoolchildren from Cascavel (PR), Brazil, by age, gender, and type of school (private and public).

\begin{tabular}{|c|c|c|c|c|c|c|c|c|c|c|}
\hline \multirow{3}{*}{ Variable } & \multicolumn{5}{|c|}{ Female } & \multicolumn{5}{|c|}{ Male } \\
\hline & \multicolumn{2}{|c|}{ Private } & \multicolumn{2}{|c|}{ Public } & \multirow{2}{*}{$p$} & \multicolumn{2}{|c|}{ Private } & \multicolumn{2}{|c|}{ Public } & \multirow{2}{*}{$p$} \\
\hline & $M$ & SD & $M$ & SD & & M & SD & M & SD & \\
\hline \multicolumn{11}{|c|}{ Body mass (kg) } \\
\hline 7 & 26.9 & 7.4 & 22.3 & 4.3 & $<0.001$ & 25.8 & 5.6 & 22.8 & 4.0 & $<0.001$ \\
\hline 8 & 28.7 & 5.7 & 25.2 & 4.8 & $<0.001$ & 30.1 & 7.6 & 26.0 & 5.2 & $<0.001$ \\
\hline 9 & 29.9 & 5.6 & 27.9 & 5.4 & $<0.01$ & 33.2 & 7.6 & 29.2 & 6.1 & $<0.001$ \\
\hline 10 & 35.3 & 10.1 & 32.2 & 7.1 & $<0.05$ & 36.5 & 7.9 & 32.4 & 7.5 & $<0.001$ \\
\hline \multicolumn{11}{|c|}{ Height $(\mathrm{cm})$} \\
\hline 7 & 126.9 & 8.2 & 119.8 & 6.0 & $<0.001$ & 124.8 & 6.8 & 120.9 & 5.7 & $<0.001$ \\
\hline 8 & 131.9 & 6.4 & 126.1 & 5.6 & $<0.001$ & 132.6 & 6.6 & 126.9 & 5.6 & $<0.001$ \\
\hline 9 & 133.9 & 5.9 & 131.6 & 5.5 & $<0.01$ & 136.6 & 6.1 & 132.8 & 6.1 & $<0.001$ \\
\hline 10 & 140.3 & 7.1 & 137.4 & 7.2 & $<0.05$ & 140.9 & 5.9 & 136.8 & 6.7 & $<0.001$ \\
\hline \multicolumn{11}{|c|}{$B M I\left(k g / m^{2}\right)$} \\
\hline 7 & 16.4 & 2.9 & 15.5 & 2.0 & $<0.05$ & 16.5 & 2.7 & 15.6 & 1.8 & $<0.05$ \\
\hline 8 & 16.4 & 2.5 & 15.8 & 2.3 & 0.05 & 16.9 & 3.0 & 16.0 & 2.3 & $<0.05$ \\
\hline 9 & 16.6 & 2.5 & 16.0 & 2.4 & 0.10 & 17.7 & 3.1 & 16.5 & 2.6 & $<0.01$ \\
\hline 10 & 17.7 & 3.8 & 17.0 & 2.8 & 0.09 & 18.3 & 3.3 & 17.2 & 3.0 & $<0.05$ \\
\hline
\end{tabular}

Note: Values expressed as mean \pm standard deviation.

M: Mean; SD: Standard Deviation; BMI: Body Mass Index.
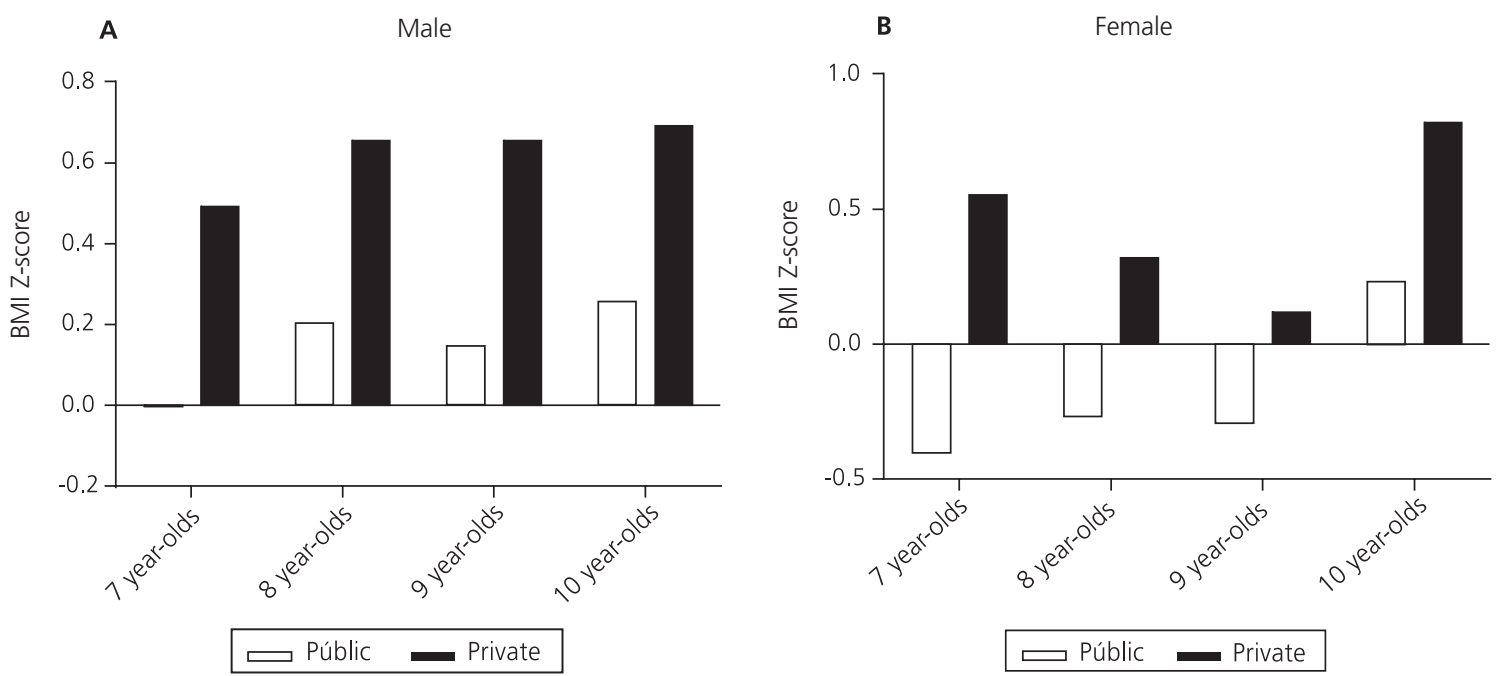

Figure 1. Body mass index Z-scores of male (A) and female (B) schoolchildren from private and public schools.

\section{DISCUSSION}

The main study findings were: (a) the prevalences of malnutrition, overweight, and obesity were $6.1 \%, 9.8 \%$, and $11.1 \%$, respectively;

(b) females were more likely to be malnourished than males; (c) 10-year-olds and students from private schools were more likely to be overweight than 7-year-olds and students from public schools; and (d) 10-year-olds and students from private schools were more likely to be obese than 7-yearolds and students from public schools.

Although childhood malnutrition decreased in Brazil in the last years', the present result 
Table 3. Nutritional status of schoolchildren from Cascavel (PR), Brazil, by age, gender, and type of school.

\begin{tabular}{|c|c|c|c|c|c|c|c|c|}
\hline \multirow{2}{*}{ Variable } & \multicolumn{2}{|c|}{ Normal weight } & \multicolumn{2}{|c|}{ Underweight } & \multicolumn{2}{|c|}{ Overweight } & \multicolumn{2}{|c|}{ Obese } \\
\hline & $\%$ & $95 \% \mathrm{Cl}$ & $\%$ & $95 \% \mathrm{Cl}$ & $\%$ & $95 \% \mathrm{Cl}$ & $\%$ & $95 \% \mathrm{Cl}$ \\
\hline \multicolumn{9}{|l|}{ Gender } \\
\hline Male & 80.4 & $79.0-82.0$ & 0.9 & $0.9-1.0$ & 11.2 & $9.9-12.3$ & 7.4 & 7.1-7.4 \\
\hline Female & 65.2 & $63.2-66.9$ & 11.6 & $10.4-12.9$ & 8.4 & $8.2-8.5$ & 14.8 & $13.3-16.0$ \\
\hline \multicolumn{9}{|c|}{ Age (years) } \\
\hline 7 & 74.6 & 72.8-76.1 & 7.5 & 7.4-7.7 & 8.7 & $8.6-8.8$ & 9.2 & $9.1-9.3$ \\
\hline 8 & 69.3 & $67.4-70.9$ & 7.8 & $7.6-8.0$ & 12.0 & $10.7-13.1$ & 10.9 & $9.6-12.0$ \\
\hline 9 & 75.5 & $74.1-77.5$ & 5.2 & $4.9-5.3$ & 8.6 & $8.6-8.8$ & 10.7 & $9.0-11.2$ \\
\hline 10 & 72.1 & $70.2-73.7$ & 3.7 & $3.5-3.9$ & 10.2 & $9.0-11.2$ & 14.1 & $12.6-15.4$ \\
\hline \multicolumn{9}{|c|}{ Type of school } \\
\hline Public & 75.4 & 73.7-77.0 & 6.2 & $6.0-6.4$ & 9.2 & $9.1-9.3$ & 9.2 & $9.0-9.2$ \\
\hline Private & 64.7 & $62.7-66.6$ & 6.0 & $5.8-6.2$ & 11.9 & 10.6-13.0 & 17.5 & 15.9-18.9 \\
\hline Total & 73.0 & $71.3-74.6$ & 6.1 & $6.0-6.4$ & 9.8 & $9.7-9.9$ & 11.1 & $9.6-12.0$ \\
\hline
\end{tabular}

Note: \%: relative frequency.

95\% Cl: 95\% Confidence Interval.

Table 4. Association between nutritional status and sociodemographic factors in schoolchildren from Cascavel (PR), Brazil, by gender, age, and type of school.

\begin{tabular}{|c|c|c|c|c|c|c|}
\hline & \multicolumn{2}{|c|}{ Underweight } & \multicolumn{2}{|c|}{ Overweight } & \multicolumn{2}{|c|}{ Obese } \\
\hline & OR & IC95\% & OR & IC95\% & OR & IC95\% \\
\hline \multicolumn{7}{|l|}{ Gender } \\
\hline Male & 1.00 & & 1.00 & & 1.00 & \\
\hline Female & 15.9 & $8.28-30.52$ & 1.07 & $0.81-1.41$ & 0.69 & $0.43-1.10$ \\
\hline \multicolumn{7}{|c|}{ Age (years) } \\
\hline 7 & 1.00 & & 1.00 & & 1.00 & \\
\hline 8 & 1.35 & $0.96-1.90$ & 1.08 & $0.73-1.61$ & 1.23 & $0.66-2.30$ \\
\hline 9 & 1.13 & $0.80-1.60$ & 1.03 & $0.69-1.53$ & 0.92 & $0.48-1.78$ \\
\hline 10 & 1.25 & $0.87-1.79$ & 1.53 & $1.04-2.26$ & 1.17 & $0.60-2.29$ \\
\hline \multicolumn{7}{|c|}{ Type of school } \\
\hline Public & 1.00 & & 1.00 & & 1.00 & \\
\hline Private & 0.82 & $0.60-1.12$ & 1.63 & $1.20-2.22$ & 2.88 & $1.80-4.61$ \\
\hline
\end{tabular}

Note: The normal weight group was defined as reference.

OR: Odds Ratio; 95\% Cl: 95\% Confidence Interval.

indicates a prevalence of malnutrition of $6.1 \%$ in the municipality of Cascavel (PR), so apparently it continues to be an important public health problem. Cases of malnutrition seem to recur in the state ${ }^{19,20}$, as shown by a study from the municipality of Maringa with 4,609 students aged 6 to 11 years $^{19}$, which reported a prevalence of malnutrition of $8.0 \%$, higher than the study prevalence and the Brazilian mean $(4.1 \%)^{1}$. In addition a study from Arapoti (PR) ${ }^{20}$ with 1,647 children aged 6 to 10 years found a prevalence of malnutrition (22.7\%) approximately five times higher than the Brazilian mean, which reinforces the concern with this outcome in the interior of Paraná, especially because of the problems caused by malnutrition on childhood development, such as delayed growth and development, neuromotor and intellectual involvement, and low immune function ${ }^{21}$.

These findings show that malnutrition has not been eliminated in Brazil as this outcome still occurs frequently in children. Malnutrition has 
many causes, mainly quality of basic sanitation and household socioeconomic status ${ }^{1}$. In this study, malnutrition was associated with sex: girls were 16 times more likely to be malnourished. This result is consistent with studies with children from other countries, such as Italy ${ }^{8}$ and Iran $^{22}$. Although other factors related to malnutrition were not investigated, one cannot discard the possible influence of maternal behavior on the nutritional status of their children ${ }^{23}$, since they tend to perceive excess weight in their daughters negatively, probably because of the image attributed by society to the female shape ${ }^{24}$. On the other hand, from the maternal viewpoint, male children should have a vigorous body, with great dimensions ${ }^{25}$.

In our study, overweight and obesity prevalence rates were $9.8 \%$ and $11.1 \%$, respectively. These prevalence rates are lower than the national prevalences for overweight (33.5\%) and obesity (14.3\%) in children aged 5 to 9 years ${ }^{1}$, and lower than the prevalence of overweight (17\%), but not of obesity (7\%), in children aged 6 to 10 years from the municipality of Maringa, located in the north of Paraná26. Moreover, the study prevalence rate of obesity was lower than the $14.1 \%$ found by a recent meta-analysis of Brazilian children and adolescents ${ }^{4}$. These differences may be related to behavioral determinants, such as time spent on computer games and boys' easy access to unhealthy foods, since girls are more selective about healthy foods ${ }^{2,6,7}$. However, the present study did not target these determinants for analysis.

Although the prevalence of excess weight (overweight and obesity) is a typical characteristics of middle-income countries ${ }^{8,21}$, this scenario may be partly justified by the Brazilian food profile, which is high in animal fat and commercially processed foods, factors apparently associated with higher socioeconomic status 2,11,12,21,27. Such factors contribute not only to the accumulation of body fat but also to the development of numerous disorders, and chronic and degenerative diseases, such as diabetes, high blood pressure, dyslipidemia, and cardiopathy ${ }^{5}$. Even though food intake and level of physical activity have not been controlled for in the study sample, there is plenty of evidence in the literature that an inappropriate diet is specifically associated with better socioeconomic status, being one of the causes of weight gain².

Our study found a higher prevalence of obesity in girls, which is in disagreement with a higher nationwide prevalence of obesity in males $(\sim 16 \%)^{1,4}$. Nonetheless, other municipalities in the state of Paraná, such as Apucarana (PR) ${ }^{28}$ and Arapoti $(P R)^{21}$, found similar prevalences of obesity.

Another important aspect found by the present study was the association between overweight and age, as 10-year-olds were 1.53 times more likely to be overweight than 7-yearolds. This finding corroborates other Brazilian studies that found a higher prevalence of overweight (35.6\%) in 9-year-olds'. However, there is no literature consensus on any specific age group as predictor of overweight and/or obesity. This fact may be illustrated by the situation in Kenia, where the prevalence of obesity (31\%) was greater in children aged 5 to 9 years ${ }^{10}$. On the other hand, the highest prevalence of obesity in Thailand (20.9\%) was found in children with a mean age of 10.3 years 5 . Similarly, in Florianopólis (SC), Brazil, the highest prevalence of obesity (11.2\%) was found in adolescents aged 10 to 17 years ${ }^{29}$.

Salomons et al..$^{20}$ found overweight and obesity prevalences of $19.5 \%$ and $22.2 \%$, respectively, in children aged 6 to 10 years from Paraná, regardless of age. These data reinforce the hypothesis that the problem of childhood obesity in Brazil affects children of all age groups ${ }^{3}$.

Regarding type of school, children from private schools were almost three times more likely to develop obesity than their public school peers, corroborating Miranda et al. ${ }^{11}$, who found higher prevalences of overweight (22.6\%) and obesity $(33.4 \%)$ in children aged 8 to 10 years from private schools. These differences were also 
found in other Brazilian municipalities ${ }^{3,13}$. Yet, a study from Rio de Janeiro (RJ) did not find different nutritional status in children aged 5 to 10 years from public and private schools ${ }^{12}$. This outcome may be related to a set of variables associated with socioeconomic level, so children from private schools are more likely to develop sedentary behavior and buy food at the school snack bar ${ }^{12-14}$.

This fact reinforces the need of adopting healthy food habits, especially during childhood, given the obesity-related risks, which may increase later in life ${ }^{26}$. In this sense, schools can play an essential role in health promotion, encouraging the adoption of healthy habits, autonomy, and biopsychosocial potentialities ${ }^{30}$.

Until now most Brazilian studies on children's nutritional status have nothing but confirmed the literature reports of the growing obesity rates. Nevertheless, the present study emphasized the high prevalence of malnutrition in children from Cascavel, PR. Hence, the present results may encourage the establishment of public policies that aim to fight malnutrition, especially in this municipality, and of preventive measures that reduce overweight and obesity by adopting strategies that increase the level of physical activity, improve the healthiness of foods sold in school snack bars, and reduce sedentary behavior by practicing educational activities.

The present study has some limitations that cannot be ignored. The absence of information about sociocultural factors, food habits, sexual maturation (especially in children aged 9 to 10 years), habitual level of physical activity, and sedentary behavior may have important implications on children's nutritional status. What is more, the sample composition did not respect the proportion of public-to-private school students, since this proportion was 0.14 in the population and 0.29 in the sample. Therefore, it is possible that the study sample size may explain some of the differences between private and public schools. Nonetheless, the present study was concerned with analyzing the behavior of both boys and girls, from public and private schools. Additionally, the inclusion of schools located in different regions and the high number of study children enabled the production of data more representative of the municipality of Cascavel (PR), Brazil.

\section{CONCLUSION}

This study found prevalence rates of malnutrition, overweight, and obesity of $6.1 \%$, $9.8 \%$, and $11.1 \%$, respectively, in schools in the municipality of Cascavel (PR), Brazil. Moreover, the greatest difference between students from public and private schools regarded the prevalence of obesity (public $=9.2 \%$ vs. private $=17.5 \%$ ). On the other hand, girls were more likely to be malnourished, and 10-year-olds were more likely to be overweight than 7-year-olds. Finally, private school children were 1.63 and 2.88 times more likely to develop overweight and obesity, respectively.

\section{ACKNOWLEDGMENTS}

We thank the Conselho Nacional de Desenvolvimento Científico e Tecnológico for the grants of research productivity and the Fundação de Amparo à Pesquisa do Amazonas for the master's grant. Additionally, we would like to especially thank all participants who contributed voluntarily to participate in this study, the regional teaching core of the municipality of Cascavel (PR), Brazil, and the public and private schools that allowed and enabled data collection in their facilities.

\section{CONTRIBUTIONS}

KES SILVA, AA BARROS FILHO, and ES CYRINO were the intellectual mentors of the study. AA BARROS FILHO and ES CYRINO advised the study team. KES SILVA and A PELEGRINI collected data. KES SILVA, A PELEGRINI, AA PINTO, and ERV RONQUE identified studies to include in the manuscript contextualization/ discussion. KES SILVA, A PELEGRINI, AA PINTO, and ERV RONQUE performed data tabulation and/or analysis. All authors contributed to data interpretation, and initial writing and final review of the manuscript. 


\section{REFERE N CES}

1. Instituto Brasileiro de Geografia e Estatística. Pesquisa de orçamentos familiares, 2008-2009: antropometria e estado nutricional de crianças, adolescentes e adultos no Brasil. Rio de Janeiro: IBGE; 2010.

2. Leal VS, Lira PIC, Menezes RCE, Oliveira JS, Costa EC, Andrade SLLS. Malnutrition and excess weight in children and adolescents: A review of Brazilian studies. Rev Paul Pediatr. 2012; 30(3):415-22. http:// dx. doi.org/10.1590/S0103-05822012000300017

3. Chaves APB, Queiroz LFR, Abreu MAA, Medeiros KB. Overweight and child obesity: A public health problem in schoolchildren from North to South of the country. Enferm Brasil. 2011; 10(6):371-6. http:// dx.doi.org/10.1186/s40608-014-0030-4

4. Aiello AM, Melo LM, Souza Nunes M, Soares da Silva A, Nunes A. Prevalence of obesity in children and adolescents in Brazil: A meta-analysis of crosssectional studies. Curr Pediatr Rev. 2015; 11(1):36-42.

5. Sukhonthachit P, Aekplakorn W, Hudthagosol C, Sirikulchayanonta $C$. The Association between obesity and blood pressure in Thai public school children. BMC Public Health. 2014; 14(1):729-36. http://dx.doi.org/10.1186/1471-2458-14-729

6. Xie X, Wu H, Lee T, Wang CM, Zhou X, Lu Y, et al. Gender differences in home environments related to childhood obesity in Nanchang, China. Child Obes. 2014; 10(5):416-23. http://dx.doi.org/10.10 89/chi.2013.0164

7. Chung EK, Romney MC. Social determinants of childhood obesity: Beyond individual choices. Curr Pediatr Rev. 2012; 8(3):237-52.

8. Lazzeri G, Rossi S, Pammolli A, Pilato V, Pozzi T, Giacchi MV. Underweight and overweight among children and adolescents in Tuscany (Italy). Prevalence and short-term trends. J Prev Med Hyg. 2008; 49(1):13-21.

9. Van Niekerk SM, Grimmer K, Louw Q. The prevalence of underweight, overweight and obesity in a multiracial group of urban adolescent schoolchildren in the cape metropole area of cape Town: Original research. South Afr J Clin Nutr. 2014; 27(1):18-24.

10. Mwaniki EW, Makokha AN. Nutrition status and associated factors among children in public primary schools in Dagoretti, Nairobi, Kenya. Afr Health Sci. 2013; 13(1):39-46. http://dx.doi.org/10.4314/ahs. v13i1.6

11. Miranda JMQ, Palmeira MV, Polito LFT, Brandão MRF, Bocalini DS, Figueira Junior AJ, et al. Prevalence of overweight and obesity in childhood in educational institutions: public vs private. Rev Bras Med Esporte. 2015; 21(2):104-7. http://dx. doi.org/10.1590/1517-869220152102143660
12. Porto $A C V$, Pires $B A B$, Coelho SC. Fast food frequency of consumption and the influence in children's nutritional profile. Acta Ped Port. 2013; 44(6):301-5.

13. Ferreira AP, Morais PP, Oliveira RJ, Ferreira CB, França NM. Overweight and obesity prevalence in schoolchildren from Taguatinga-DF. Rev Inst Ciênc Saúde. 2008; 26(2):161-6.

14. Oliveira AMA, Cerqueira EMM, Oliveira AC. Prevalence of overweight and childhood obesity in Feira de Santana-BA: Family detection x clinical diagnosis. J Pediatr. 2003; 79(4):325-8. http://dx. doi.org/10.1590/S0021-75572003000400010

15. Instituto Brasileiro de Geografia e Estatística. Cidades; 2014. [acesso 2016 maio 19]. Disponível em: http://www.cidades.ibge.gov.br/xtras/perfil.php? lang $=\&$ codmun $=410480$

16. Luiz RR, Magnanini MMF. O tamanho da amostra em investigações epidemiológicas. In: Medronho RA, Bloch KV, Luiz RR, Werneck GL, organizadores. Epidemiologia. São Paulo: Atheneu; 2009:415-27.

17. Gordon CC, Chumlea WC, Roche AF. Stature, recumbent length, and weight. In: Lohman TG, Roche AF, Martorell R, editors. Anthropometric standardization reference manual. Champaign: Human Kinetics; 1988. pp. 3-8.

18. World Health Organization. Multicentre Growth Reference Study Group. WHO Child Growth Standards. Length/height-for-age, weight-for-age, weight-for-length, weight-for-height and body mass index-for-age: Methods and development. Geneva: WHO; 2006.

19. Rosaneli CF, Baena CP, Auler F, Nakashima ATA, Netto-Oliveira ER, Oliveira AB, et al. Elevated blood pressure and obesity in childhood: A cross-sectional evaluation of 4,609 schoolchildren. Arq Bras Cardiol. 2014; 103(3):238-44. http://dx.doi.org/10.5935/ abc. 20140104

20. Salomons E, Rech CR, Loch MR. Nutritional status of six to ten-year-old schoolchildren in the municipal education system of Arapoti, Paraná, Brazil. Rev Bras Cineantropom Desempenho Hum. 2007; 9(3):244-9.

21. Galiano LP, Abril FM, Ernert A, Bau AM. The double burden of malnutrition and its risk factors in school children in Tunja. Arch Latinoam Nutr. 2012; 62(2):119-26.

22. Saeidlou SN, Babei F, Ayeromlou P. Malnutrition, overweight, and obesity among urban and rural children in north of west Azerbijan, Iran. J Obes. 2014; 2014:1-5. http://dx.doi.org/10.1155/2014/5 41213

23. Molina $M C B$, De Faria CP, Montero P, Cade NV. Correspondence between children's nutritional 
status and mothers' perceptions: A populationbased study. Cad Saúde Pública. 2009; 25(10):2285-90. http://dx.doi.org/10.1590/S0102-3 $11 \times 2009001000018$

24. Boa-Sorte N, Neri LA, Leite MEQ, Brito SM, Meirelles $A R$, Luduvice FBS, et al. Maternal perceptions and self-perception of the nutritional status of children and adolescents from private schools. J Pediatr. 2007; 83(4):349-56. http://dx.doi.org/10.1590/s0 021-75572007000500011

25. Mendonça MRT, Silva MAM, Rivera IR, Moura AA. Prevalence of overweight and obesity in children and adolescents from the city of Maceió (AL). Rev Assoc Med Bras. 2010; 56(2):192-6. http://dx. doi.org/10.1590/S0104-42302010000200018

26. Rosaneli CF, Auler F, Manfrinato CB, Rosaneli CF, Sganzerla $C$, Bonatto $M G$, et al. Evaluation of the prevalence and nutritional and social determinants of overweight in a population of schoolchildren: $A$ cross-sectional analysis of 5,037 children. Rev Assoc Med Bras. 2012; 58(4):472-6. http://dx.doi.org/10. 1590/S0104-42302012000400019

27. Costa MAP, Vasconcelos AGG, Fonseca MJM. Prevalence of obesity, overweight and abdominal obesity and its association with physical activity in a federal University. Rev Bras Epidemiol. 2014; 17(2):421-36. http://dx.doi.org/10.1590/1809-45 03201400020011ENG

28. Guedes DP, Paula IG, Guedes JERP, Stanganell LCR. Prevalence of overweight and obesity among children and adolescents: Estimative according to gender, age, and socioeconomic status. Rev Bras Educ Fís Esporte. 2006; 20(3):151-63.

29. Pelegrini A, Silva DAS, Petroski EL, Glaner MF. Nutritional status and associated factors in schoolchildren living in rural and urban areas. Rev Nutr. 2010; 23(5):839-46. http://dx.doi.org/10.15 90/S1415-52732010000500014

30. Zanirati VF, Lopes ACS, Dos Santos LC. Contribution of extended school hours to the nutritional and physical activity profile of schoolchildren. Rev Panam Salud Publica. 2014; 35(1):38-45.

Received: November 30, 2015 Final version: May 30, 2016 Approved: June 22, 2016 